\title{
Effect of Occupational Stress on Life Satisfaction among Private and Public School Teachers
}

\author{
Shehnaz Bano ${ }^{1}$ \\ Dr. Sadia Malik 2
}

\begin{abstract}
The study intends to examine the effect of occupational stress on life satisfaction among school teachers. The sample was consisted of 200 school teachers from private and public sector schools of Bhakkar city. Questionnaires are used to assess the response of teachers. Descriptive statistics, Regression analyses and independent sample t- test are used to examine the data. Main findings of the study reveal that higher occupational stress is related to lower life satisfaction $(\beta=.52, p<.001)$. Significant gender differences are found, as female teachers reported more severe job stress as compared to male teachers $(t=2.09, p<.05)$. Findings also indicate that there is no significant difference in occupational stress in private teachers and public school teachers. In the last, some limitations and suggestions are also included to facilitate future research studies.
\end{abstract}

Keywords: Job stress, life satisfaction, work place, impact

\section{Introduction}

Work is not always a way of endless satisfaction and accomplishment but some time, it becomes a source of stress, discomfort and irritation. Teacher's work innovalues mentals and physical risks and challenges as they require a lot of will power and energy to handle their classroom situations coupled with their personal and family affairs. This regular trend of work may cause a lot of stress for them. The aim of this study is to single out the effect of occupational role stress on life satisfaction among teacers. In addition, it explores the gender differences and also the differences in private and government school teachers.

Life satisfaction assesses is said to be a person's all over rational decision of life. According to Diener, Emmons, Larsen, and Griffin (1985) life satisfaction is an ability to judge wisely which depends upon a comparing of one's situation with a suitable standard. Nevertheless, one of the fundamental elements in life satisfaction research is that the understanding of satisfaction is necessarily relay on the individual's subjective feelings instead of what experts define in objective way (Diener \& Suh,1997). Thus, individuals are believed to construct a judgment of what makes their life full of comfort (Fox \& Kahneman, 1992). Beehr (1995) describes job stress as a condition in which some distinctiveness of the work position is thought to cause deprived mental or physical fitness. In addition, Akinboye, Akinboye and Adeyemo (2002) illustrate job stress as a harmful expressive and physical reaction that occur when job load are incompatible with the resources and requirements of the worker. Part of what serves as the major stimulators of job-related stress for educational administrators occurred in the work setting (Swent \& Gmelch, 1977). There are many factors that effect on the teacher decision about leaving or staying in this field. These factors can be job stress, job

1 Shehnaz Bano, Department of Psychology, University of Sargodha, shaan 9659@gmail.com 2 Dr. Sadia Malik, Assistant Professor, Department of Psychology, University of Sargodha, drsadiamalik13@gmail.com \begin{tabular}{llll|l}
\hline JISR-MSSE & Volume 12 & Number 1 & January-June 2014 & 17
\end{tabular} 
dissatisfaction, flexibility and self-efficacy (Chan, 2008). Usually they include stressors in the field of work role such as workload; management; class size; role ambiguity and disagreement; the pressures of the teachers' roles; poor working conditions; little appreciation lack of decision-making power; student defiance; lack of useful communication and most importantly teacher's emotional demands (Blix, Cruse,\& Mitchel, 1994; Cooper \& Kelly, 1993; Punch \& Tuetteman, 1990).

Many researchers concern the teacher stress and the findings indicted that there has been strong association among psychological and physical strength and job stress of teachers (William \& Gersch, 2009). Marais (1992) found a broad range of stressors with many directions that mainly encircled the work conditions, such as inadequate working condition, role conflict and ambiguity, students' problem of risk of unemployment, little reimbursement in administrative and many others. Stereotypes and biases against marginal group are also important. According to Pelsma and Richard (1988) job stress of teachers and job satisfaction were found to be strongly parallel. They also explained that quality of teacher's work life is shaped by the degree of their stress and job satisfaction. In England, Stress is considered the main reason of job dissatisfaction, role illness and before time retirements. The elements that create stress in organizations are ecological factors and the behavior formed as a consequence of the force of these elements on the individual (Amason, Allen \& Holmes, 1999).

Srivastava (1991) surveys 300 workers of the Life Insurance Corporation and demonstrated significant positive correlation between different aspects of job stress and indications of psychologically poor health. Anxiety is related to stress due to role ambiguity and role stagnation. Dwivedi (1997) found the extent of trust, distrust, and ORS to find degree of relationship between private and public sector institutes. The sample consisted of 62 executives from private and 55 from public sectors. Results revealed that level of stress was high in low level performance organizations and decrease in high performance institutes.

Malik (2011) conducted a research on bank employees in Quetta, Pakistan. A total of200 participants were part of this research in which 100 belong to private banks and 100 were from public sector. Results revealed the significant difference in perceiving stress in both sectors as public bank employees reported more job stress as compared to private employee. Khurshid, Butt and Malik (2011) reported that university teachers face moderate to high level of job stress as a whole. The teachers in private universities practiced more stress as compared to public sector universities. In public universities, the main reason of job stress is their association with their contemporaries while in private universities, high workload cause occupational role stress. In their research of Gadzella, (1990); Mohanty and Mishra, (1998), found positive correlation between the degree and scope of occupational stress among private and public sector executives.

Gender also plays an important role in occupation role stress and life satisfaction as evident by the literature. A research conducted in Pakistan by Kousar (2004) on elementary school principals showed that female school supervisor feel more job stress than male administrators. Male teachers that work as supervisor can handle stress related to their work place and staff member as compared to female supervisor. In another study, Laughlin (1984) reported female with more job stress than males. Female have to work home and other house hold tasks that cause the distinction between males and females(Mohammadi \& Capel, 2007). The finding

\begin{tabular}{l|llll}
\hline 18 & January-June 2014 & Volume 12 & Number 1 & JISR-MSSE
\end{tabular}


of Guthric (2006) also indicated the female working in education and related sectors have to face more work stress than their male contemporaries. When the condition that act as source of stress were examined, it was found that females vary from male in their opinion about the stressful aspects work (Brog \& Falzon, 1991; Punch \& Tuetteman, 1996).

Chaplain (1995) explored occupational stress in primary schools in UK. The results of this study results revealed significant gender differences, age differences as well as difference in level of job experiences. According to this study, Male teachers reported more job stress in their educational duties and student's behavior as compared to female teachers. There were high scores of female teachers in professional concerns. Results indicated that only one third from all teachers showed contentment with their job. Singh and Sehgal, (1995) highlighted the patterns of stress and strain among men and women as well as single and dual career couples. They found that male and female managers did not differ significantly on various stress dimensions. Difference in gender was however found in strains. Women were characterized by anxiety, whereas men exhibited more symptoms of somatic problems comparing the single and dual couples. It was found that male managers with spouses working experienced higher workload than managers whose spouses were not working. In strains also single career male managers had less irritability that dual career male managers din overall single career male managers had better psychological well-being than others did working women managers had better physical well-being that their working husband did but had poorer psychological wellbeing.

Ahmad, Bharadwaj, and Narula (1985) assess stress levels among 30 executives from both the public and private sector, using an ORS scale to measure ten dimensions of role stress. Their study reveals significant differences among private and government sector workers in three dimensions of job stress-work isolation, role ambiguity, and self-role distance. The authors also establish the insignificant effect of several background factors, such as age, level of education, income, marital status, and work experience.

\subsection{Significance of Study}

Academic sector is the most suitable setting for the study of occupational stress in Pakistan because educators have been at high risk of job stress.(Sigler \& Wilson, 1988). In Pakistan, education has become more common than past years. Due to lack of proper facilities, increasing number of schools and high burden of work, teachers suffer in many problems and tensions in their duties as the managements are facing competitive pressure from other schools. This may lead to stress that definitely influence their life satisfaction as well as their physical and psychological health. In western countries, many researchers have proved relationship of occupational stress; life satisfaction an job satisfaction; but in Pakistan this area has not been scrupulously investigated. There are many researches on the relationship between job stress and job satisfaction but effect of stress on worker's life satisfaction is not thoroughly investigated. It is a common observation that stressful encounters over a long period of time direct to reduce mental well-being and overall life satisfaction. (Burke \& Greenglass, 1995).

The main aims of this study are:

- To investigate the effect of occupational stress on life satisfaction.

- To find out the gender difference in term of occupational stress.

- To explore occupational stress in private and public school teachers.

\begin{tabular}{lll|l}
\hline JISR-MSSE & Volume 12 & Number 1 & January-June 2014 \\
\hline
\end{tabular}




\subsection{Hypotheses}

$\mathrm{H}_{1}$ : Occupational stress would have negative impact on teacher's life satisfaction. $\mathrm{H}_{2}$ : Female teachers would experience significantly more severe occupational stress as compared to male teachers.

H3: Teachers in Private sector would experience more job stress than in Public sector.

\section{Research Methodology}

For this purpose, Data was collected by using demographic sheet, organizational role stress scale and satisfaction with life scale. Organizational role stress (Pareek, 1983) is used to examine the occupational stress in teachers. This scale used with necessary modification by using 25 items with five subscales Inter role distance, role expected conflict, role overload, role ambiguity and self role distance according to local setting. Life Satisfaction was measured with the" satisfaction with life scale" (Diener, Emmons, Larsen \& Griffin, 1985). The SWLS consists of 5 items. Respondent were requested to give response on these items across a 7 point likert scale that ranges from 1 (strongly disagree) to 7 (strongly agree) and the measured showed the higher internal consistency. Reliability of SWLS is $(r=.69)$.

A total of 200 male and female school teachers were included in the sample. Five private and 5 public sector school teachers were consulted for this purpose. Purposive sampling technique was used for data collection. All the possible efforts were made to make them feel at ease and respond to the scales with full concentration. Before the administration of the test, an introduction was given to the teachers. There was no time limit and participants were asked to give their responses according to their personal experience as accurately as possible. A total of 230 questionnaires were distributed in which 200 responses were achieved.

In accordance with the various objectives of the studies, different statistical techniques is used by applying SPSS (Version 17.00); Descriptive techniques such as mean, standard deviation frequency and percentage are used to explain the nature of distribution of scores. Regression analysis is used to see the significant impact of occupational stress on life satisfaction. Independent sample t-test is used to see the gender differences and also used to compare the occupational stress in private and public schools among teachers. 


\section{Results}

3.1 Demographic Characteristics of Participants.

Table 1 The Frequency and Percentage of Participant's Demographics

\begin{tabular}{lll}
\hline Characteristics & $\mathbf{N}$ & $\%$ \\
\hline Gender & 100 & $50 \%$ \\
Male & 100 & $50 \%$ \\
Female & & \\
Institution & 100 & $50 \%$ \\
Private & 100 & $50 \%$ \\
Public & & \\
Marital status & 93 & $44.2 \%$ \\
Married & 107 & $55.8 \%$ \\
Single & & \\
Education & 24 & $11.7 \%$ \\
F.A/F.sc & 65 & $29.2 \%$ \\
B.A/B.sc & 97 & $55.8 \%$ \\
M.A/M.sc & 14 & $3.3 \%$ \\
M.phil & & \\
\hline
\end{tabular}

Table 1 indicated the demographic information of school teachers regarding their gender, sector, marital status and education.

Table 2 Linear regression analysis showing the impact of occupational role stress on Life satisfaction among Teachers $(\mathrm{N}=\mathbf{2 0 0})$

\begin{tabular}{lllll}
\hline Variables & $\beta$ & $\Delta \mathrm{R}^{2}$ & \multicolumn{2}{l}{ Interval 95\%CI } \\
\cline { 5 - 6 } & & & $\mathrm{LL}$ & $\mathrm{UL}$ \\
Occupational stress & $.52^{* * *}$ & .38 & -.39 & -.24 \\
\hline$* * * p<.001$ & & & &
\end{tabular}

Table 2

revealed that there is significant impact of occupational role stress on life satisfaction $F$ $(1,198)=74.47, p<.001$. This model explained $38 \%$ of variance in the dependent variable.

Table 3 Multiple regression analysis showing the impact of subscales of occupational stress on life satisfaction $(\mathbf{N}=120)$

\begin{tabular}{lcccc}
\hline Variables & $\beta$ & $\Delta R^{2}$ & \multicolumn{2}{l}{ Interval 95\%CI } \\
\cline { 3 - 4 } & & & LL & UL \\
\hline Inter role distant & $.30^{*}$ & .59 & .49 & .21 \\
Role expected conflicts & $.37^{* * *}$ & & 1.02 & .46 \\
Role overload & $.35^{* * *}$ & 1.11 & .46 \\
Role Ambiguity & $.21^{* *}$ & .67 & .17 \\
Self-role distant & $.26^{*}$ & .12 & .07 \\
\hline
\end{tabular}

$* p<.05, * * * p<.001$ 
Table 3 revealed that there is significant effect of all these variables on life satisfaction. $\mathrm{F}$ $(1,198)=32.93, p<.001$ his model explained $59 \%$ of variance in life satisfaction

Table 4 Mean, standard deviation, and $t$ values for male and female for study variables $(\mathrm{N}=\mathbf{2 0 0})$

\begin{tabular}{lcccccccc}
\hline & $\begin{array}{c}\text { Male } \\
(n=100)\end{array}$ & & $\begin{array}{c}\text { Female } \\
(n=100)\end{array}$ & \multicolumn{3}{c}{$\begin{array}{c}\text { Interval } \\
95 \% C I\end{array}$} \\
\hline Variable & $M$ & $S D$ & $M$ & $S D$ & $T$ & $L L$ & $U L$ & Cohen's \\
Occupational Role stress & 41.98 & 11.43 & 49.52 & 12.85 & $2.09^{*}$ & 19.32 & 13.40 & 0.90 \\
Life satisfaction & 10.08 & 5.69 & 6.65 & 2.67 & $1.25^{*}$ & 9.53 & 11.26 & 0.89 \\
inter role distance & 7.97 & 3.07 & 10.45 & 2.83 & $1.02^{* *}$ & 2.97 & 1.42 & 0.61 \\
role expected conflict & 9.07 & 3.08 & 8.82 & 2.92 & $1.45^{*}$ & 5.08 & 3.21 & 0.65 \\
role overload & 3.70 & 3.70 & 3.44 & 2.44 & $1.61^{*}$ & 5.32 & 3.91 & 0.41 \\
role ambiguity & 3.52 & 2.64 & 2.64 & 3.52 & $1.81^{*}$ & 4.02 & 1.77 & 0.49 \\
self role distance. & 3.50 & 3.50 & 3.81 & 3.38 & 2.37 & 5.56 & 1.46 & 0.11 \\
\hline
\end{tabular}

To test the gender differences, independent sample t-test is used. Mean of male teachers on OCRS was 41.98 and mean of female teachers was 49.52 . Table 4 shows that female school teachers experience more severe job stress as compare to male school teachers. That support the second hypotheses. The results further reveal that females experience significantly more inter role distance as compared to male Teachers. Results also indicate significant difference between male and female teachers in term of role expected conflict. Similarly, females who had more overload experience significantly more role overload stress as compared to male teachers. Results depicted that that females experienced significantly more role ambiguity as compared to male teachers, whereas; no significant difference between male and female teachers in term of self-role distance.

Table 5 Mean, standard deviation, and t values for Gov't and Private Teachers for study variables $(\mathbf{N}=\mathbf{2 0 0})$

\begin{tabular}{|c|c|c|c|c|c|c|c|c|}
\hline \multirow{3}{*}{$\begin{array}{l}\text { Variable } \\
\text { Occupational Role } \\
\text { stress }\end{array}$} & \multicolumn{2}{|c|}{$\begin{array}{l}\text { Public } \\
(n=100)\end{array}$} & \multicolumn{2}{|c|}{$\begin{array}{l}\text { Private } \\
(n=100)\end{array}$} & \multicolumn{3}{|c|}{$\begin{array}{l}\text { Interval } \\
95 \% C I\end{array}$} & \multirow[b]{2}{*}{ Cohen's } \\
\hline & $\mathrm{M}$ & $\mathrm{SD}$ & M & SD & $\mathrm{t}$ & LL & UL & \\
\hline & 42.95 & 12.80 & 44.05 & 10.46 & .75 & 3.15 & 6.08 & 0.13 \\
\hline Life satisfaction & 10.21 & 6.32 & 9.60 & 4.13 & .42 & 2.04 & 2.77 & 0.05 \\
\hline
\end{tabular}

Independent sample t-test in Table 5 showed no significant difference in job stress among Government and private school teachers.

\section{Discussion}

It was assured that occupational role stress has an impact on life satisfaction. Results show that occupational role stress is a significant predictor of low Life satisfaction. The study further intended to investigate the impact of inter role distance, role expected conflict, role overload, role ambiguity and self role distance on life satisfaction. Findings reveal significant impact of all these stresses on life satisfaction. A number of cross-culture studies (Auerbach \& Stephan, 1996; Beckwith \& Bill, 1996; Borg, 1990; Caplin, 1985; Chandler, 1976) supported

\begin{tabular}{l|llll}
\hline 18 & January-June 2014 & Volume 12 & Number 1
\end{tabular} 
these findings. In fact when a person fails to give proper time to his family due to his overload working sceduale it become impossible for him to satisfy the conflicting demands of various people related to him. Sometime organizational responsibilities interfere with his extra organizational roles, and some time a person experience conflict between his values and what he have to do in his role, All these occupational stresses affect the a person life satisfaction badly. An atmosphere of mistrust and hostility is associated with role ambiguity as well as a low level of communication, satisfaction and psychological well-being. In addition, there are other factor that show that job stress causes low life satisfaction such as minority status lack of enthusiasm etc.

It was hypothesized that the female teachers would experience significantly more severe occupational stress as compared to male teachers. Analysis of gender differences in present study indicated that female teachers reported more job stress as compare to male teachers. The results of present study are consistent with previous literature (Halim, 1979; Barke, \& Keland, 1981; Lazarus, 1991; Levi, 1989; Locke \& Taylor, 1990). The reason of gender difference in term of occupational stress might be that female teacher are mostly depressed under the pressure of too much burden of job and home responsibilities while male teachers are less pensive about their classes and performance and have less responsibilities of home so they are overall more satisfied with their job and as a whole their life. Sometime, females have to face work place harassment that decrease their job performance. If a female fails to keep balance in her job and family then conflict arises. Thus both job stress and domestic conflict decrease her over all life satisfaction. Males have to face these problems less as compare to females.

It was also hypothesized that Teachers who had private jobs experience significantly more severe occupational stress as compared to teachers having Goverment job. The data of study suggested that the job stress in government and private school teachers is to some extent similar. These finding are not consistent with those of (Elman \& Gilbert, 1984; Hall, 2003; Hunt, 2006; Johnstone,1993; Pervaiz \& Haneef, 2003; Seemeen (1983) which indicate that government school teacher show more stress. In Pakistan, the reason of not having the significant difference of job stress among government and private school teachers may be that now all the government school teacher have promoted in to English medium school. The government school teachers who are less educated and low command on English language have to face stress in term of teaching the student and also pressure of head of the school and seniors to give the good results of students. Thus it is concluded that other than educational sector many other factors may contribute in job stress such as job situation age, personal interest, internal characteristics physical and mental health.

Besides, this study has certain limitation; such as smaller sample size because the sample was recruited from one city of Pakistan therefore one need to be careful in making generalization of findings. The study is also limited to the teachers of just fewer schools. Furthermore, in the study socioeconomic status of the teachers was not controlled which might have contributed in job stress and life satisfaction.

\section{Conclusion}

The study concludes that job stress has negative effect on life satisfaction. It is further found that females are more stressed due to their job than male teachers. In term of educational

\begin{tabular}{lllll}
\hline JISR-MSSE & Volume 12 & Number 1 & January-June 2014 & 19
\end{tabular}


sector, private and public sector school teachers share more or less equal stress. The findings of this research have implications for promoting our understanding of occupational role stress and life satisfaction in Pakistani academic system in order to introduce effective preventive measures to reduce the incidents of occupational stress and to increase life satisfaction.

\section{References}

Singh, A.K. \& Sehgal, P. (1995). Men and women in transition: patterns of stress, strain and social relations. Vikalpa, 20 (1), 13-22.

Halim, A. (1979). Individual and interpersonal moderate of employee's reaction to job characteristics: A re-examination. Personnel Psychology, 32, 121-138.

Akinboye, J. O., Akinboye, D. O \& Adeyemo, D. A. (2002). Coping with Stress in Life and Work Place. Ibadan: Stirling- Hordern Publishers (Nig) Ltd.

Mohannadi, A. \& Capel, S. (2007). Stress in physical education teachers in Qatar. Social Psychology of Education, 10, 55-75.

Antoniou, A. S., Polychroni, F. and Vlachakis, A.N. (2006). Gender and age differences in occupational stress and professional burnout between Primary and High-School Teachers in Greece. Journal of Managerial Psychology, 21 (7), 682-690.

Auerbach, S. M. (1996). Stress: Behavioral and psychological responses. An International Encyclopedia of Psychology. Volume 01. London.

Bailey, T., Eng, W., Frisch, M., \& Snyder, C. R. (2007). Hope and optimism as related to life Satisfaction. Journal of Positive Psychology, 2(3), 168-69.

Barke, M. \& Keland, J. (1981): Organizational stress and job satisfaction. Journal of Social Psychology, 100(2) 235-244.

Barke, M. (2003): Organizational stress and job satisfaction. Journal of Social Psychology, $100(2), 235-244$

Burke, R. J. \& Greenglass, E. (1995). A longitudinal study of psychological burnout in teachers. Human Relations, 48, 187-202

Beehr, T. A. (1995). Psychological Stress in the Workplace. London: Routledge.

Beckwith, B. E. (1996). Stress and endocrine system. An International Encyclopedia of Psychology. 01. London.

Blix, A. G., Cruse, R. J., Mitchell, B. M. M. B., \& Blix, G. G. (1994). Occupational stress among universit teachers. Educational Research, 36, 157-170.

Borg, M.G. \& Falzon, J.M. (1991). Sources of Teacher Stress in Maltese Primary Schools. Research in Education, 46, 1-15.

\begin{tabular}{l|llll}
\hline 18 & January-June 2014 & Volume 12 & Number 1
\end{tabular} 
Boyle,G. J (1995). A structural model of the dimensions of teacher stress. British Journal of Educational Psychology, 65,49-67.

Caplin, M.L. (1985). Psychological stress in work. Management and Labour studies. A Psychological Abstract.Volume 73. No.04-06.

Chaplain, R. (1995), Stress and job satisfaction: A study of English primary school teachers, Educational Psychology, 15, 4, 473-489.

Chandler, S. K. (1976). Teacher stress and Job satisfaction as they relate to the implementation of a court ordered Desegregation Plan. Dissertation Abstract International, 36, 7.

Chan, Y., Yoon, J., Wu, J.T., Kim, H.J., Pan, K.T., Yim, J., \& Chien, C.T. (2008). Supplementary Material. Jural of Cell Science. 121, 19.

Cooper, C. L., Marshall, J. (1976), Occupational sources of stress: a review of the literature relating to coronary heart disease and mental ill health. Journal of Occupational Psychology, 49 (1): 11-28.

Diener, E., Emmons, R. A., Larsen, R. J., \& Griffin, S. (1985). Satisfaction with Life Scale. Journal of Personality Assessment, 49, 71-75.

Diener, E., \& Suh, E. (1997). Measuring quality of life: Economic, social, and subjective indicators. Social Indicators Research, 40, 189-216.

Dwivedi, R. K. (1997). Trust and role stress. In D. M. Pestonjee \& U. Pareek (Eds.), Studies in Organizational Role Stress and Coping. New Delhi: Rawat.

Elman, M., \& Gilbert, L. (1984). Coping strategies for role conflict in married professional women with children. National Council on Family Relations.

Farooqi, Y. N. (2010). Doing Research in Social Sciences: From Idea to Action. Germany: VDM.

Fox, C. R., \& Kahneman, D. (1992). Correlations, causes and heuristics in surveys of life satisfaction. Social Indicators Research, 27 ,221-234

Guthrie, R. (2006). Teachers and Stress. Australia \& New Zealand Journal of Law \& Education, $11(1), 5-18$.

Gadzella, B. M.; Ginther, D.,W.; Tomcala, M; Bryant, G., W. (1990). Stress as perceived by professionals. Psychological Report. Dec. Vol. 67(3, Pt 1) 979-983.

Hunt. J. K. (2006), Job stressors and their effects on physical health, emotional health, and job satisfaction in a university, Journal of Educational Administration, 32(1), 59-78.

Hall, E. K. \& Chan, D.W. (1996). Teacher stress and guidance work in Hong Kong secondary school teachers, British Journal of Guidance \& Counseling, 24, 199-211. 
Johnstone, M. (1993). Teachers Workload and Associated Stress. Scottish Council for Research in Education. Research report 53. United Kingdom; Scotland.

Kousar, S., Fatima, N., \& Bashir, F. (2004). A study of stress management strategies adopted by elementary school principles. University of the Punjab, Lahore.

Kantas, A. (2013). Measuring burnout and work engagement: Factor structure, invariance, and latent mean differences across Greece and Netherlands, International Journal of Business Science and Applied Management, 7, 40-52.

Khurshid, F, Butt, Z. U \& Malik, S. K. (2011). Occupational role stress of the public and private sector universities teachers, Language in India, 11 (8), 1.

Laughlin, R.S., Folkman, S. (1984), Stress, Appraisal and Coping: New York: Springer.

Lazarus, R.S. (1991). Psychological stress in the workplace. Journal of Social Behaviour and Personality, 6(4), 13.

Levi, L. (1989): Occupational stressor, biological stress and worker's health. Journal of Occupational and Environmental Health, 1142-1154.

Locke, E.A. \& Taylor, M.S (1990). Stress coping and the Meaning of Work. In W. Nord \& A.P. Brief (Eds.) The meaning of work. New York: McGraw-Hill, 135-170.

Malik, N. (2011). A study on occupational stress experienced by private and public sector bank employees in Quetta city. African Journal of Business Management, 5(8), 3063 3070 .

Marais, J. L. (1992). Faktore wat stress veroorsaak by onderwysers in die Oranje- Vrystaat en Kaapprovinsie. Suid Afrikaanse Tydskrif vir Opvoedkunde, 12. 305- 309.

Montgomery, C. \& Rupp, A. A. (2005). A meta-analysis for exploring the diverse causes and effects of stress in teachers. Canadian Journal of Education, 28 (3), 458-486.

Pervaz,S., \& Hanif, R. (2003). Levels and sources of work stress among women school teachers. Pakistan Journal of Psychological Research, 18(3-4), 97-108.

Punch, K.F. \& Tuetteman, E. (1996). Reducing teacher stress: The effects of support in the work environment. Research in Education, 56, 63-72.

Sigler, C.D. \& wilson, E.C. (1995). Measuring occupational stress: The job stress survey. In R. Crandall, and P.L. Perrewe, (Eds), Occupational Stress: A Handbook (pp. 5169). Washington D.C.: Taylor \& Francis.

Srivastava, A. K. (1991). A study of the role stress-mental health relationship as a moderator by adopting coping strategies. Psychological Studies, 3, 192-197.

\begin{tabular}{l|llll}
\hline 18 & January-June 2014 & Volume 12 & Number 1
\end{tabular} 
Swent, B. \& Gmelch, W. H. (1997). Stress at the Desk and How to cope creatively. Eugene,or: Oregon School Study Council.

Truch, S., \& Singh, E. (1995). Teacher Burnout. Novato, CA: Academic Therapy Press Publications,

Van Dick, R., Phillips U., Marburg, M. \& Wagner, U. (2001). Stress and strain in teaching: structural equation approach. British Journal of Educational Psychology, 71, 243-259

Westman, M.; \& Etzion, D. (1999). The crossover of strain from school principals to teachers and vice versa. Journal of Occupational Health Psychology, 4, 269- 278.

Williams, M., \& Gersh, I. (2004). Teaching in mainstream and special schools: are the stresses similar or different? British Journal of Special Education, 31(3), 157-162. 